\title{
POLA BAKTERI AEROB PENYEBAB INFEKSI NOSOKOMIAL PADA RUANGAN NEONATAL INTENSIVE CARE UNIT (NICU) BLU RSUP PROF. DR. R. D KANDOU MANADO
}

\author{
${ }^{1}$ Malindra Saleh \\ ${ }^{2}$ Fredine E.S Rares \\ ${ }^{3}$ Standy Soeliongan \\ ${ }^{1}$ Kandidat Skripsi Fakultas Kedokteran Universitas Sam Ratulangi \\ ${ }^{2}$ Bagian Mikrobiologi Fakultas Kedokteran Universitas Sam Ratulangi \\ Email: malindra_saleh@yahoo.com
}

\begin{abstract}
Nosocomial infection is an infection which occurs in the hospital caused by microbacteria from the hospital. Infection in neonatal is a serious issue in each hospital until today. Neonatal Intensive Care Unit (NICU) is a care unit for newborn who needs special care. Nosocomial infection is often happening to babies in NICU. The objective is to determine the pattern of aerob bacteria causes nosocomial infection in Neonatal Intensive Care Unit (NICU) BLU RSUP Prof. Dr. R. D. Kandou Manado. The research used descriptive method with prospective study. The amount of samples are 30 and was taken according to category of care room, room instruments, medical equipments and air. Based on the results, there are 11 species of bacterias included Bacillus subtilis 13 samples (43,3\%), Serratia liquefaciens 4 samples (13,3\%), Lactobacillus 3 samples (10\%), Enterobacter agglomerans 2 samples (6,7\%) and Klebsiella pneumoniae 2 samples (6,7\%), Proteus mirabilis 1 sample (3,3\%), Proteus vulgaris 1 sample (3,3\%), Streptococcus non hemoliticus 1 sample $(3,3 \%)$, Diplococcus 1 sample (3,3\%), gram-positive Coccus 1 sample (3,3\%) and gram-negative Coccus 1 sample (3,3\%).
\end{abstract}

Keywords: nosocomial infection, NICU, aerob bacteria

\begin{abstract}
Abstrak: Infeksi nosokomial adalah infeksi yang terjadi di rumah sakit oleh kuman yang berasal dari rumah sakit. Infeksi nosokomial yang terjadi pada bayi baru lahir sampai saat ini merupakan masalah yang serius disetiap rumah sakit. Neonatal Intensive Care Unit (NICU) merupakan unit perawatan untuk bayi baru lahir yang memerlukan perawatan khusus. Infeksi nosokomial sering terjadi terutama pada bayi yang mendapat perawatan di NICU. Tujuan dari penelitian ini yaitu untuk mengetahui pola bakteri aerob penyebab infeksi nosokomial pada ruangan Neonatal Intensive Care Unit (NICU) BLU RSUP Prof. Dr. R. D Kandou Manado. Penelitian ini menggunakan metode deskriptif dengan pendekatan studi prospektif. Sampel yang diteliti berjumlah 30 sampel dan di ambil berdasarkan kategori ruang perawatan, perabotan ruangan, peralatan medis dan udara. Berdasarkan hasil penelitian ditemukan 11 spesies bakteri yaitu Bacillus subtilis 13 sampel (43,3\%), Serratia liquefaciens 4 sampel (13,3\%), Lactobacillus 3 sampel (10\%), Enterobacter agglomerans 2 sampel (6,7\%) dan Klebsiella pneumoniae 2 sampel (6,7\%), Proteus mirabilis 1 sampel (3,3\%), Proteus vulgaris 1 sampel (3,3\%), Streptococcus non hemolitikus 1 sampel (3,3\%), Diplokokus 1 sampel (3,3\%), Kokus gram positif 1 sampel (3,3\%) dan Kokus gram negatif 1 sampel (3,3\%).
\end{abstract}

Kata kunci: infeksi nosokomial, NICU, bakteri aerob 
Infeksi nosokomial (IN) merupakan suatu masalah yang nyata diseluruh dunia dan terus meningkat. ${ }^{1}$ Infeksi nosokomial disebut juga sebagai infeksi yang berhubungan dengan pelayanan kesehatan atau Health-care Associated Infection (HAIs). ${ }^{2}$ Jenis infeksi yang paling sering terjadi adalah infeksi saluran kemih, infeksi saluran napas, infeksi luka, infeksi kulit dan jaringan lunak, dan septikemia. ${ }^{3}$ Infeksi nosokomial yang terjadi pada bayi baru lahir sampai saat ini masih merupakan masalah yang serius disetiap rumah sakit. Selain meningkatkan waktu serta biaya perawatan rumah sakit, infeksi nosokomial juga menyebabkan tingginya angka morbiditas, mortalitas serta meningkatkan risiko palsi serebral/kecacatan pada bayi yang bertahan hidup. ${ }^{4}$ Neonatal Intensive Care Unit (NICU) adalah ruang perawatan intensif untuk bayi yang memerlukan pengobatan dan perawatan khusus, guna mencegah dan mengobati terjadinya kegagalan organ-organ vital. $^{5}$ Infeksi nosokomial sering terjadi terutama pada bayi yang mendapat perawatan di NICU. ${ }^{4}$ Suatu penelitian yang dilakukan oleh World Health Organization (WHO) tahun 2006 menunjukkan bahwa sekitar 8,7\% dari 55 rumah sakit dari 14 negara di Eropa, Timur tengah, dan Asia Tenggara serta Pasifik terdapat infeksi nosokomial, khususnya di Asia Tenggara sebanyak 10\%. ${ }^{6}$ Hasil prevalensi survei Center for Disease Control and Prevention (CDC) di Amerika Serikat, menyatakan bahwa pada tahun 2011 terdapat 722.000 kasus infeksi nosokomial. $^{7}$ Sementara itu, data WHO menunjukkan, terdapat 10 juta kematian neonatal dari 130 juta bayi yang lahir setiap tahunnya. ${ }^{8}$ Di Indonesia yaitu di 10 RSU pendidikan, infeksi nosokomial cukup tinggi yaitu 6-16\% dengan rata-rata 9,8\% pada tahun 2010. ${ }^{9}$ Berdasarkan penelitian pada ruang perawatan intensif anak RSMH Palembang tahun 2009 menunjukkan bahwa terdapat 22 pasien yang mengalami infeksi nosokomial. Dengan kuman terbanyak berturut-turut adalah Acinetobacter sp (27\%), Klebsiella sp (19\%) dan Staphylococcus sp (19\%). Penelitian ini dilakukan pada 30 penderita yang dirawat minimal selama 48 jam atau setelah 48 jam perawatan dan diduga memiliki manifestasi infeksi nosokomial. ${ }^{10}$ Berdasarkan hal tersebut, peneliti tertarik untuk melakukan penelitian mengenai pola bakteri aerob penyebab infeksi nosokomial pada ruangan Neonatal Intensive Care Unit (NICU) BLU RSUP Prof. DR. R. D Kandou Manado.

\section{METODE PENELITIAN}

Penelitian ini menggunakan metode deskriptif dengan pendekatan studi prospektif. Penelitian ini dilakukan pada bulan November 2014 sampai Januari 2015. Pengambilan sampel dilakukan di ruangan Neonatal Intensive Care Unit (NICU) BLU RSUP Prof. Dr. R. D Kandou Manado. Sampel pada penelitian ini berjumlah 30 yang diambil dari ruangan perawatan yaitu dinding dan lantai, perabotan ruangan yaitu pintu, meja dan kursi, peralatan medis yaitu inkubator, infus, ventilator dan suction, dan udara. Pemeriksaan sampel dilakukan di Laboratorium Mikrobiologi Fakultas Kedokteran Universitas Sam Ratulangi Manado.

\section{HASIL PENELITIAN}

Pengambilan sampel pada ruangan Neonatal Intensive Care Unit (NICU) BLU RSUP Prof. Dr. R. D Kandou Manado menghasilkan sebanyak 30 sampel. Pengambilan sampel dapat diuraikan dalam tabel berikut. 
Jurnal e-Biomedik (eBm), Volume 3, Nomor 1, Januari-April 2015

Tabel 1. Uraian Pengambilan Sampel Berdasarkan pertumbuhan bakteri pada media isolasi Agar Nutrien dan Agar Mac Conkey

\begin{tabular}{|c|c|c|}
\hline Kategori & Sampel & $\begin{array}{l}\text { Jumlah } \\
\text { sampel }\end{array}$ \\
\hline Ruang perawatan & $\begin{array}{l}\text { Lantai, } \\
\text { dinding }\end{array}$ & 9 \\
\hline Perabotan ruangan & $\begin{array}{l}\text { Pintu, Meja, } \\
\text { Kursi }\end{array}$ & 5 \\
\hline Peralatan medis & $\begin{array}{l}\text { Infus, } \\
\text { Ventilator, } \\
\text { Suction, } \\
\text { Inkubator }\end{array}$ & 10 \\
\hline Udara & $\begin{array}{l}\text { Pagi dan } \\
\text { siang }\end{array}$ & 6 \\
\hline Total & & 30 \\
\hline \multicolumn{3}{|c|}{$\begin{array}{l}\text { laka sampel dapat didistribus } \\
\text { bagai berikut. } \\
\text { abel 2. Distribusi Pertumbuhan Bakteri }\end{array}$} \\
\hline Media Isolasi & $\begin{array}{l}\text { Nutrien } \\
\text { Agar }\end{array}$ & $\begin{array}{l}\text { ac } \\
\text { onkey } \\
\text { gar }\end{array}$ \\
\hline $\begin{array}{l}\text { Ada } \\
\text { Pertumbuhan }\end{array}$ & 30 & \\
\hline $\begin{array}{l}\text { Tidak Ada } \\
\text { Pertumbuhan }\end{array}$ & 6 & \\
\hline Total & 30 & \\
\hline
\end{tabular}

Sedangkan untuk hasil pewarnaan gram dapat disajikan pada tabel berikut.
Tabel 3. Hasil Pewarnaan Gram

\begin{tabular}{lll}
\hline \multicolumn{1}{c}{ Gram } & $\begin{array}{l}\text { Jumlah } \\
\text { sampel }\end{array}$ & $\begin{array}{c}\text { Persenta } \\
\text { se (\%) }\end{array}$ \\
\hline $\begin{array}{l}\text { Bakteri gram } \\
\text { positif }\end{array}$ & 18 & 60 \\
$\begin{array}{l}\text { Bakteri rram } \\
\text { negatif }\end{array}$ & 6 & 20 \\
$\begin{array}{l}\text { Gram positif dan } \\
\text { negatif }\end{array}$ & 6 & 20 \\
\hline Total & 30 & 100 \\
\hline
\end{tabular}

Dan untuk identifikasi bakteri dapat dilihat pada tabel dibawah ini.

Tabel 4. Hasil Identifikasi Bakteri

\begin{tabular}{llc}
$\begin{array}{l}\text { Hasil indentifikasi } \\
\text { Bakteri }\end{array}$ & Jumlah & $\begin{array}{l}\text { Presentas } \\
\text { e (\%) }\end{array}$ \\
\hline Bacillus subtilis & 13 & 43,3 \\
$\begin{array}{l}\text { Serratia } \\
\text { liquefaciens }\end{array}$ & 4 & 13,3 \\
$\begin{array}{l}\text { Lactobacillus } \\
\text { Enterobacter }\end{array}$ & 3 & 10 \\
$\begin{array}{l}\text { agglomerans } \\
\text { Klebsiella }\end{array}$ & 2 & 6,7 \\
$\begin{array}{l}\text { Pneumoniae } \\
\text { Proteus mirabilis }\end{array}$ & 1 & \\
$\begin{array}{l}\text { Proteus vulgaris } \\
\text { Steptococcus non }\end{array}$ & 1 & 3,3 \\
hemolitikus & & 3,3 \\
$\begin{array}{l}\text { Diplokokus } \\
\text { Kokus gram }\end{array}$ & 1 & 3,3 \\
positif & 1 & 3,3 \\
$\begin{array}{l}\text { Kokus gram } \\
\text { negatif }\end{array}$ & 1 & 3,3 \\
\hline Total & 30 & 100 \\
\hline
\end{tabular}

diuraikan berdasarkan kategori sampel yang diambil. Kategori sampel yang diambil terdiri dari ruangan perawatan, perabotan ruangan, peralatan medis dan udara. 
Saleh, Rares, Soeliongan: Pola bakteri aerob...

Tabel 5. Hasil Identifikasi Bakteri Kategori Ruang Perawatan

\begin{tabular}{lcc}
\hline Bakteri & Jumlah & $\begin{array}{l}\text { Persentase } \\
(\%)\end{array}$ \\
\hline $\begin{array}{l}\text { Serratia } \\
\text { liquefaciens }\end{array}$ & 2 & 22.2 \\
$\begin{array}{l}\text { Lactobacillus } \\
\text { Bacillus subtilis }\end{array}$ & 2 & 22.2 \\
$\begin{array}{l}\text { Klebsiella } \\
\text { pneumoniae }\end{array}$ & 2 & 22.2 \\
$\begin{array}{l}\text { Enterobacter } \\
\text { agglomerans }\end{array}$ & 1 & 11.1 \\
Kokus gram negatif & 1 & 11.1 \\
\hline Total & 9 & 100 \\
\hline
\end{tabular}

Tabel 6. Hasil Identifikasi Bakteri Kategori Perabotan Ruangan

\begin{tabular}{lll}
\hline Bakteri & $\begin{array}{l}\text { Jumla } \\
\mathrm{h}\end{array}$ & $\begin{array}{l}\text { Persentas } \\
\mathrm{e}(\%)\end{array}$ \\
\hline $\begin{array}{l}\text { Bacillus subtilis } \\
\text { Klebsiella } \\
\text { pneumoniae }\end{array}$ & 3 & 60 \\
$\begin{array}{l}\text { Kokus } \\
\text { positif }\end{array}$ & 1 & 20 \\
\hline Total & 1 & 20 \\
\hline
\end{tabular}

\section{BAHASAN}

Berdasarkan hasil penelitian ditemukan 11 spesies bakteri. Bacillus subtilis adalah bakteri yang paling banyak ditemukan. Kemudian ditemukan Serratia liquefaciens pada sampel lantai dan udara. Serratia liquefaciens merupakan bakteri gram negatif dan masuk dalam famili Enterobacteriaceae. Bakteri ini dapat menyebabkan pneumonia, bakteremia dan endokarditis terutama pada pasien yang dirawat di rumah sakit. ${ }^{11}$ Pada penelitian pola kuman dan sensitiftas antibiotik di
Tabel 7. Hasil Identifikasi Bakteri Kategori Peralatan Medis

\begin{tabular}{lll}
\hline Bakteri & Jumlah & $\begin{array}{l}\text { Persenta } \\
\text { se (\%) }\end{array}$ \\
\hline Bacillus subtilis & 8 & 80 \\
Lactobacillus & 1 & 10 \\
Proteus mirabilis & 1 & 10 \\
\hline Total & 10 & 100 \\
\hline
\end{tabular}

Tabel 8. Hasil Identifikasi Bakteri Kategori Udara

\begin{tabular}{lll}
\hline Bakteri & Jumlah & $\begin{array}{l}\text { Persent } \\
\text { ase } \\
(\%)\end{array}$ \\
\hline $\begin{array}{l}\text { Serratia liquefaciens } \\
\begin{array}{l}\text { Enterobacter } \\
\text { agglomerans }\end{array}\end{array}$ & 2 & 33.3 \\
$\begin{array}{l}\text { Proteus vulgaris } \\
\text { Streptococcus }\end{array}$ & 1 & 16.7 \\
hemolitikus & 1 & 16.7 \\
Diplococcus & 1 & 16.7 \\
\hline Total & 1 & 16.7 \\
\hline
\end{tabular}

ruang perinatologi yang dilakukan oleh Kardana di RSUP Sanglah Denpasar menerangkan bahwa Serratia liquefaciens adalah salah satu bakteri penyebab sepsis neonatorum. $^{12}$

Lactobacillus ditemukan pada sampel dinding dan suction. Bakteri ini merupakan organisme anaerob yang dapat bersifat aerotoleran dan $\alpha$-hemolotik, kadangkadang menyerupai bentuk kokobasil yang serupa dengan Streptococcus viridans. ${ }^{11}$ Pada bayi baru lahir bakteri ini adalah bakteri utama pada pemberian susu namun bersifat nonpatogen. ${ }^{13}$ 
Enterobacter agglomerans disebut juga Pantoea agglomerans adalah bakteri batang gram negatif yang tergabung dalam famili Enterobacteriaceae. Pada penelitian yang dilakukan oleh Mardaneh dkk, bakteri Enterobacter agglomersans ditemukan pada isolasi dan identifikasi bubuk susu formula di NICU. Sedangkan pada penelitian ini Enterobacter agglomerans ditemukan pada sampel dinding dan udara. $^{14}$

Klebsiella pneumoniae ditemukan pada sampel lantai dan meja. Berdasarkan penelitian yang dilakukan oleh Auriti dkk, Klebsiella spp adalah orgenisme utama penyebab infeksi nosokomial di NICU. Kolonisasi Klebsiella pada penelitian tersebut banyak ditemukan pada saluran pencernaan. Oleh karena tingginya kasus pembedahan abdomen pada bayi di NICU. ${ }^{15}$

Proteus mirabilis dan Proteus vulgaris adalah kelompok bakteri gram negatif yang menimbulkan infeksi pada manusia hanya bila bakteri keluar dari saluran cerna. Pada penelitian ini Proteus mirabilis ditemukan pada sampel inkubator dan Proteus vulgaris ditemukan pada sampel udara. Organisme ini terdapat pada saluran kemih dan menimbulkan bakteremia, pneumonia, dan infeksi fokal pada pasien yang lemah atau pada pasien yang menerima infus intravena. Proteus mirabilis adalah organisme penyebab terjadinya meningitis hingga komplikasi menjadi abses serebral pada bayi baru lahir. ${ }^{16}$

Streptococcus non hemolitikus adalah spesies Streptococcus yang tidak dapat menimbulkan pola hemolisa pada agar darah. Streptococcus bovis adalah salah satu spesies yang memiliki karakteristik tersebut. Bakteri ini adalah bagian dari flora normal usus yang kadang-kadang menyebabkan endokarditis, dan bakteremia pada pasien karsinoma kolon. ${ }^{11}$ Pada penelitian ini, Streptococcus non hemolitikus ditemukan pada sampel udara. Sedangkan pada penelitian yang dilakukan oleh Gerber dkk, Streptococcus bovis adalah organisme yang dapat menyebabkan bakteremia dan meningitis pada bayi baru lahir. $^{17}$

Diplokokus adalah bakteri berbentuk sferik, lancip, atau seperti biji kopi yang biasanya berpasangan sebagai akibat pemisahan yang tidak sempurna setelah pembelahan sel pada satu bidang. ${ }^{18}$ Bakteri yang tergolong dalam bakteri diplokokus adalah Neisseria sp, Haemophilus, Acinetobacter, Brucella, Streptococcus pneumonia dan Enterococcus. ${ }^{19}$

Diplokokus, kokus gram positif dan kokus gram negatif adalah hasil identifikasi bakteri yang tidak dilanjutkan. Oleh karena itu, tidak dapat ditentukan nama spesies bakteri tersebut.

Pada penelitian tentang bakteri aerob dan bakteri penyebab penyakit di Neonatal Intensive Care Unit di rumah sakit Dr. Wahidin Sudirohusodo Makassar yang dilakukan oleh Suriyanti dkk menyatakan bahwa pada peralatan medis ditemukan bakteri Acinetobacter calcoaceticus. ${ }^{20}$ Berbeda dengan penelitian ini, dimana pada peralatan medis ditemukan bakteri Bacillus suptilis, Lactobacillus dan Proteus mirabilis.

Semua peralatan medis atau peralatan perawatan pasien yang dimasukkan ke dalam jaringan tubuh, sistem vaskuler atau melalui saluran darah harus selalu dalam keadaan steril sebelum digunakan. Sterilisasi peralatan yang berkaitan dengan perawatan pasien secara fisik dengan pemanasan pada suhu $\pm 121^{\circ} \mathrm{C}$ selama 30 menit atau pada suhu $134^{\circ} \mathrm{C}$ selama 13 menit dan harus mengacu pada petunjuk penggunaan alat sterilisasi yang digunakan. $^{21}$

Penelitian tentang udara rumah sakit di Nigeria oleh Awosika dkk, menyatakan bahwa di NICU ditemukan bakteri Staphylococcus aureus, Klebsiella spp dan Candida albicans. ${ }^{22}$ Sedangkan pada hasil penelitian ini disajikan bahwa di udara terdapat bakteri Serratia liquefaciens, Enterobacter agglomerans, Proteus vulgaris, Streptococcus non hemolitikus dan Diplococcus.

Penghawaan ruangan NICU BLU RSUP Prof. Dr. R. D Kandou Manado 
menggunakan ventilasi buatan yaitu Air Conditioning (AC). Rumah sakit yang menggunakan pengatur udara (AC) sentral harus diperhatikan cooling-towernya agar tidak menjadi perindukan bakteri. Dan untuk AHU (Air Handling Unit) filter udara harus dibersihkan dari debu dan bakteri atau jamur. $^{21}$

Penelitian yang dilakukan oleh Jurczak dkk tentang karakteristik mikrobiologi klinik pada infeksi nosokomial di NICU menyajikan bakteri batang gram negatif khususnya Klebsiella spp yang paling banyak ditemukan. Sedangkan pada penelitian ini, bakteri batang gram negatif adalah bakteri kedua terbanyak yang ditemukan. Bakteri gram negatif yang ditemukan pada penelitian ini yaitu Serratia liquefaciens, Enterobacter agglomerans, Klebsiella pneumoniae, Proteus mirabilis dan Proteus vulgaris.

Alasan yang paling mendasar ditemukan bakteri gram negatif dalam jumlah yang tidak sedikit adalah sterilitas yang ada di rumah sakit. Bakteri ini sering ditemukan hidup di kulit tangan manusia dan memperbanyak koloninya pada suhu yang tinggi. Bakteri batang gram negatif atau golongan Enterobacteriaceae dapat menempel pada tangan tenaga kesehatan, peralatan medis dan udara. ${ }^{23}$ Hal ini erat kaitannya dengan kejadian infeksi silang.

Kejadian infeksi silang di rumah sakit erat kaitannya dengan kebiasaan cuci tangan oleh petugas kesehatan. Dari berbagai tulisan diketahui bahwa kejadian infeksi silang rumah sakit kebanyakan terjadi melalui tangan petugas rumah sakit yang tercemar kuman karena kontak dengan pasien, karier, bahan/alat atau dengan lingkungan yang tercemar. ${ }^{24}$

Produksi endotoksin dari bakteri batang gram negatif bukan hanya dapat mengganggu fungsi organ, tetapi juga dapat mengakibatkan gangguan pada keseluruhan sistem dalam tubuh. Syok septik adalah gejala yang paling sering muncul dan menimbulkan kematian pada bayi. ${ }^{23}$

\section{SIMPULAN}

Berdasarkan hasil penelitian pola bakteri aerob penyebab infeksi nosokomial pada ruangan Neonatal Intensive Care Unit (NICU) BLU RSUP Prof. DR. R. D Kandou Manado maka dapat dirumuskan kesimpulan dari 30 sampel ditemukan 11 spesies bakteri yaitu yaitu Bacillus subtilis, Serratia liquefaciens, Lactobacillus, Enterobacter agglomerans, Klebsiella pneumoniae, Proteus Mirabilis, Proteus vulgaris, Streptococcus non hemolitikus, Diplokokus, Kokus gram positif dan Kokus gram negatif. Bacillus subtilis merupakan bakteri yang terbanyak ditemukan.

\section{SARAN}

Agar pada penelitian selanjutnya dilakukan uji kepekaan antibiotik bakteri aerob penyebab infeksi nosokomial pada ruangan Neonatal Intensive Care Unit (NICU). Sterilisasi ruang perawatan, perabotan ruangan, peralatan medis dan udara di ruangan NICU lebih diperhatikan. Pemeliharaan kebersihan lingkungan ruang perawatan harus lebih diupayakan. Serta perilaku sanitasi perorangan bagi tenaga medis maupun keluarga pasien perlu diperhatikan demi menghindari terjadinya infeksi silang.

\section{UCAPAN TERIMA KASIH}

Penulis mengucapkan terima kasih kepada semua pihak yang turut serta menyumbangkan pikiran dalam penulisan artikel ini.

\section{DAFTAR PUSTAKA}

1. Irianto K. Mikrobiologi medis. Bandung: Alfabeta; 2013. h. 10613.

2. Kementerian Kesehatan Republik Indonesia. Surveilans infeksi di rumah sakit. [diunduh 26 September 2014]. Tersedia dari http://buk.depkes.go.id/index.php?opti on $=$ com_content\&view $=$ article $\& i d=12$ 3:surveilans-infeksi-di-rumah-sakit

3. Bamford $\mathbf{K}$, Gillespie $\mathbf{S}$. At a Glance Mikrobiologi medis dan infeksi. Edisi ke-3. Jakarta: Erlangga; 2009. h. 24-5. 
4. Alatas F, Satari H, Chair I, Rohsiswatmo R, Munasir Z, Windiastuti E. Gambaran Epidemiologi infeksi nosokomial aliran darah pada bayi baru lahir. Sari Pediatri. 2007;9:80-6.

5. Damarwati T. Gambaran tingkat kecemasan orang tua dari bayi yang dirawat di ruang NICU RSUP Fatmawati Jakarta. Universitas Indonesia

6. Ginting, Mardan. Infeksi nosokomial dan manfaat pelatihan keterampilan perawat terhadap pengendaliannya di ruang rawat inap penyakit dalam RSUP H. Adam Malik Medan Tahun 2001. Poltekkes Medan, 2001.

7. Centers for Disease Control and Prevention. Healthcare-associated infections (HAIs). [diunduh 26 September 2014]. Tersedia dari: http://www.cdc.gov/HAI/prevent/preve ntion.html

8. Sianturi P, Hasibuan B, Lubis B, Azlin E, Tjipta G. Gambaran pola resistensi bakteri di unit perawatan neonates. Sari Pediatri. 2013;13:431-6

9. Jeyamohan, Dharsini. Angka prevalensi infeksi nosokomial pada pasien luka operasi pasca bedah di Rumah Sakit Umum Pusat Haji Adam Malik, Medan dari bulan April sampai September 2010. Universitas Sumatera Utara

10.Kurniawan A, Triratna S, Riyanto D, Theodorus. Angka kejadian dan pola kuman infeksi nosokomial pada penderita di ruang perawatan intensif anak RSMH Palembang. JKK. 2009;41:2686-94

11.Jawetz, Melnick, Adelberg. Mikrobiologi kedokteran. Edisi ke 23. Jakarta: EGC: 2004. h. 149-52.

12.Kardana I. Pola kuman dan sensitivitas antibiotik di ruang perinatologi. Sari Pediatri. 2011;12(6):381-5

13.Feigin, Cherry, Harrison-D, Kaplan. Textbook of pediatric infectious diseases. Philadelphia: Saunders elsevier; 2009. h. 3076-3109

14.Mardaneh J, Dallal $M$ M. Isolation, identification and antimicrobial susceptibility of Pantoea (Enterobacter) agglomerans isolated from consumed powdered infant formula milk (PIF) in NICU ward. Iran J Microbiol. 2013;5(3):263-7
15.Auriti C, Ronchetti M, Pezzotti P, Marrocco G, Quondamcarlo A, Seganti G, dkk. Determinants of nosokomial infection in 6 Neonatal Intensive Care Units: An Italian Multicenter Prospective Cohort Study. Chicago journal. 2010.

16.Phan H, Lehman D. Cerebral abscess complicating Proteus mirabilis meningitis in a newborn infant. J child Neurol. 2012;27(3):405-7

17.Gerber, Jeffrey S, Glas M, Frank G, Shah S. Streptococcus bovis infection in young infants. 2006;25:1069-1073

18.Kamus saku kedokteran Dorland. Edisi ke 28. EGC

19.Diplococcus. [diunduh 22 Januari 2015]. Tersedia dari: en.m.wikipedia.org/wiki/Diplococcus

20.Suriyanti, Handayani I, Rusli B. Bakteri aerob dan bakteri penyebab penyakit di Neonatal Intensive Care Unit. Indonesian Journal Of Clinical Pathology and Medical Laboratory. 2014;20(3):180-2

21.KEPUTUSAN MENTERI KESEHATAN REPUBLIK INDONESIA Nomor 1204/MENKES/SK/X/2004 Tentang Persyaratan Kesehatan Lingkungan Rumah Sakit.

22. Microbiological assesment of indoor air of a teaching hospital in Nigeria. Asian Pacific Journal of Tropical Biomedicine. 2012;2(6):465-8

23.Jurczak A, Kordek A, Grochans E, Giedrys-Kalemba S. Clinical and microbological characteristics of hospital infections in the neonatal intensive care unit. Advance in Medical Sciences. 2007;52:23-5

24.Musadad A, Lubis A. Kejadian infeksi nosokomial saluran pencernaan di rumah sakit di DKI Jakarta. Bul. Penelit. Kesehata. 1992;20(2):79-84 